\title{
Modern Fiqh Paradigm in Indonesia: A Study of Nurcholish Majid's Though
}

\author{
Dr. Moh Dahlan, M.Ag. \\ Lecturer of Ushul Fiqih in IAIN Bengkulu Graduate Program \\ Jln Raden Fatah. Pagar Dewa, Bengkulu, Indonesia
}

\begin{abstract}
Islam as a rahmatan lil Alamin (mercy to the entire universe) religion, basically, has the passion to drive the dynamics of the human race, but in fact, it still has not reached ideal expectations because of the assumption about the door ijtihad is closed, taklid attitude, heresy and superstition, as well as textual classic ijtihad paradigm. Based on this explanation, problem formulations were stated as follows: how is the modern fiqh ijtihad paradigm built by Madjid? How is the modern fiqh ijtihad paradigm built by Madjid in Indonesia? The study used the theory of paradigm shift by Thomas S. Kuhn and theory maqasid al-shari'ah. The results of this study indicated that there was a paradigm shift from the ijtihad classical paradigm to the modern ijtihad paradigm built based on muhkamat passages, not mutashabihat passages. The paradigm shift purposes built by Madjid is to ensure the maintenance of the five principles of law construction, they are (a) maintaining religion as a means to realize the depth of faith and righteous deeds; (B) maintaining thought to realize the usage of the mind and the dynamics of science; (C) maintaining the soul in the sense of respecting and keeping the existence of human rights and fundamental freedoms; (D) maintaining the honor as a means to embody the values of equality, personal and collective dignity, and avoiding any kind of cult of other than Allah; and (e) maintaining the property as a means to maintain economic stability and equal distribution of wealth in life in Indonesia.
\end{abstract}

Keywords: Paradigm, Ijtihad, Fiqh and Modern

\section{INTRODUCTION}

Islam as religion with mercy to the entire universe, basically, has a strong passion in driving the dynamics of the human race. This is supported by the values of Islamic law, known as fiqh with its inclusive-universal characteristic. Thus, the dynamics of the human race, including Muslims, can run fairly and well. Although Islam, initially, is a religion from group of people who came from an agrarian culture in the Middle East, it is still relevant to the development of culture, including modern culture that is full of science, rationality and high complexity. ${ }^{1}$

Meanwhile, since the decline from heyday of Abbasyiyah era, the empirical reality of Muslims life up to now still has not reached the ideal expectations as the spirit and the basic values of Islam. One of the causes that perpetuate the sustainability of decline and backwardness of Muslims is Sufi practices that tend to be fatalistic, taklid attitude and believe in takhayyul. ${ }^{2}$ In addition, there is also the textual-classic ijtihad paradigm oriented to the past. Consequently,

\footnotetext{
${ }^{1}$ Modern Islamic side has been taken by jurisprudence, while its mystical has experienced classic-conservative tendencies. Nurcholish Madjid, Islam Kemodernan dan Keindonesiaan, (Bandung: Mizan, 1998), p. 79.

2 Eradication of bid'ah, taklid, and takhayyul, and must be revived ijtihad. Harun Nasution, Pembaruan dalam Islam: Sejarah Pemikiran dan Gagasan, Cet ke-14, (Jakarta: Bulan Bintang, 2011), pp. 55-56.
} 
that Muslims have difficulty in answering modern culture. ${ }^{3}$ We also cannot follow the modern culture as a whole, such as secularism and rationalism. ${ }^{4}$

The modern culture, also, has influenced the culture of Indonesia since the beginning of its Independence to the era of reform and there are still some groups of religious leaders who wanted Indonesia is based on religion, Islamic law. Meanwhile, some other groups of modernist secular still wants this country is based on the rational-secular principles. The results of that dialectic, the founders of the Republic of Indonesia formulated the ideology of Pancasila and the Constitution of the Republic of Indonesia (Constitution-RI) 1945 which has inclusive and universal characters in accommodating all the interests, aspirations and rights of plural citizens. Even though it had been changed several times, this Constitution is still in its characters, inclusive and universal, because it is derived from the essential values and noble culture of Indonesian society.

One of the reformer figures who contributed significantly in strengthening and maintaining the inclusive and universal character in Indonesia is Nurcholish Madjid. He expressed his opinion that the dynamics of the modern world experienced by Indonesia should not alienate Muslims from their life guidance but the essential values or message of Islam (fiqh) must be the guideline of their life. ${ }^{5}$ Therefore, Madjid's modern paradigm stressed the need to uphold the values of faith, rationality and humanity, ${ }^{6}$ as it - essential values of fiqh - should become the guide in life. ${ }^{7}$ Based on the description above, Madjid asserts that the modern fiqh paradigm must be built on the ijtihad paradigm which is based on muhkamat passages (i.e. clear meaning instructions with inclusive and universal character) that become a testing instrument in assessing the validity of the legal norms of fiqh. ${ }^{8}$

Madjid's fiqh reform movement is done when there is a strong demand of the textual-classical movement formalizes fiqh norms (Islamic law) in social and political life in Indonesia. Moreover, there is also the debate over the relevance of the fiqh values with modern culture. Monumental Madjid's modern fiqh idea gets the response from various groups of scientists, religious leaders or politicians - bureaucrats. The scientists, religious leaders and practitionerspoliticians who respond positively are: first, M. Amin Abdullah acknowledged that Madjid's Islamic thought has exceeded the limits of science in his time not only using textual paradigm but also the social sciences and humanities. ${ }^{9}$ Second, Lukman Hakim Saifuddin, the Minister of Religious Affairs, appreciate Madjid's Islamic reform that has encouraged an attitude of

\footnotetext{
${ }^{3}$ M. Amin Abdullah, Studi Agama: Normativitas dan Historisitas (Yogyakarta: Pustaka Pelajar, 1996)

${ }^{4}$ Universal Declaration of Human Rights (DUHAM) in 1948 makes human rights as an absolute thing to be enforced. Haryatmoko, "Apa Yang Tersisa dari Agama”, "Majalah Basis”, No. 05-06 May-June, 2002; Perveen Shaukat Ali, "Equality As A Basic Human Right in Islam" in Tahir Mahmoud (ed), Human Rights in Islamic Law (New Delhi: Jamia Nagar, 1993), p.188 and 122.

${ }^{5}$ Nurcholish Madjid, "The contemporary view about fiqh: assessing problems of Islamic law in modern age", in Budhy Munawar-Rachman (ed.), Kontekstualisasi Doktrin Islam dalam Sejarah, (Jakarta: Paramadina, 1995), p. 383.

${ }^{6}$ Madjid, "The contemporary view about fiqh: assessing problems of Islamic law in modern age", in Budhy Munawar-Rachman (ed.), Kontekstualisasi Doktrin...,pp. 384-385.

7 Madjid, "The contemporary view about fiqh: assessing problems of Islamic law in modern age", in Budhy Munawar-Rachman (ed.), Kontekstualisasi Doktrin...,pp. 385-386.

8 Madjid, "Taqlid and Ijtihad continuity and creativity problems in understanding religion message", in Budhy Munawar-Rachman (ed.), Kontekstualisasi Doktrin...,p. 341.

${ }_{9}^{\mathrm{M}}$ Amin Abdullah, Sumbangan Nurcholish Madjid atas Perkembangan Pemikiran Islam Indonesia, http://nurcholishmadjid.net/?page=news\&action=view\&id=64, retrieved on September 19 th 2016.
} 
openness and dialogue in religious life in the plurality of religious life in Indonesia. ${ }^{10}$ Third, Fachry Ali pointed out that one of the crucial and growing influence of Madjid's ideas until now is renewal of Islamic thought which then also affects student organizations (read: Islamic Students Association). ${ }^{11}$ Fourth, Franz Magnis-Suseno stated that Madjid's idea mentioning Islam as a religion of humanity has invited all mankind to rethink the position of the original Islam that is committed to respect human dignity. ${ }^{12}$ Meanwhile, scientists who are responding critically are: First, Greg Barton stated that Madjid's notion of neo-modernism has offered a comprehensive ijtihad paradigm that distinguishes it with the early modernism. However, Greg Barton thinks that Madjid's thought just exist in the elite circle, not leaving massive influence. ${ }^{13}$ Second, Maria Ulfa also argues that the Madjid's inclusive religious concept has brought chaos caused a Hindus or any other religion can claim themselves as Muslim, and will go to heaven. ${ }^{14}$ Third, M. Kamal Hasan accused Madjid as a secular modernist for advocating the "secularization". ${ }^{15}$

Based on the previous description, focus of this study can be formulated as follows: how is the modern fiqh ijtihad paradigm built by Madjid? How is the modern fiqh paradigm built by Madjid in Indonesia?

\section{THEORETICAL DISCUSSION}

The theoretical discussion of this study can be explained as follows: first, Thomas S. Kuhn said that the paradigm is the way of thinking adopted in exploring and acquiring knowledge. The way of thinking, naturally, to reach the knowledge will always experience a paradigm shift from the old paradigm to a new paradigm in accordance with the dynamics of science and the reality of mankind life. ${ }^{16}$

Secondly, literally, fiqh is a deep understanding. Fiqh, according to A. Qodri A. Azizy, is activity of understanding and giving law to a case by interpreting Qur'an and Sunnah. ${ }^{17}$ Yusuf AlQardlâwî stated, terminologically, that fiqh is knowledges of the syara' laws and have unearthed practical character of the arguments in detail. Likewise, al-Jurjani states that fiqh is

\footnotetext{
${ }^{10}$ Lukman Hakim Saifuddin, Pidato Menteri Agama Haul Cak Nur Ke-10, http://nurcholishmadjid.net/index.php?page=news\&action=view\&id=77, retrieved on September $19^{\text {th }} 2016$. 11 Fachry Ali, Hipotesa tentang Fase Perubahan Pemikiran Nurcholish Madjid, http://nurcholishmadjid.net/index.php?page=news\&action=view\&id=67, retrieved on September 19 th 2016. 12 Franz Magnis-Suseno, Agama, Kebangsaan dan Demokrasi Nurcholish Madjid dan Kemanusiaan, http://nurcholishmadjid.net/index.php?page=news\&action=view\&id=68, retrieved on September 19 th 2016. 13 Greg Barton, Gagasan Islam Liberal di Indonesia: Pemikiran Neo-Modernisme Nurcholish Madjid, Djohan Effendi, Ahmad Wahib dan Abdurrahman Wahid, trans. Nanang Tahqiq (Jakarta: Paramadina dan Pustaka Antara, 1999), pp. 511-512.

14 Maria Ulfa, "Observing religion inclusivism of Nurcholish Madjid", Jurnal KALIMAH Volume 11, No. 2, September 2013, p. 249; see also http://ejournal.unida.gontor.ac.id/index.php/kalimah/article/download/94/84, retrieved on September $19^{\text {th }} 2016$

15 M Dawam Rahardjo, "Islam and modernization: notes to the notion of Nurcholish Madjid's secularization" in Madjid, Islam Kemodernan..., p.19.

16 Paradigm as an example of actual scientific practice accepted as theory or application in a scientific study. Therefore, the paradigm is always shifting, from the old paradigm, anomaly, crisis, until the new paradigm. Thomas S. Kuhn, The Structure of Scientific Revolution (Chicago: The University of Chicago Press, 1970), pp. 10-12, and 84-85: Inayatul Ulya and Nushan Abid, "Thomas Kuhn's thought and its relevance against Islam science", in FIKRAH: Jurnal Ilmu Aqidah dan Studi Keagamaan STAIN Kudus, Volume 3, No. 2, (December 2015), pp. $254-255$. ${ }^{17}$ A. Qodri A. Azizy, Eklektisisme Hukum Nasional: Kompetisi Antara Hukum Islam dan Hukum Umum (Yogyakarta: Gama Media, 2002), pp. 2-3.
} 
knowledge obtained through the process of ijtihad. ${ }^{18}$ Meanwhile, Said Aqil al-Munawwar mentions that fiqh is the nature of Allah's scripture. From these definitions, it can be understood that fiqh is obtained through the process of ijtihad based on the source of Qur'an and Sunnah which aims to realize mankind prosperity based on the maqasid al-Shari'ah. ${ }^{19}$

Third, literally, the modern word comes from the Latin word, moderma, that means present, the latest or sophisticated. It can be said that modern word has orientation related to the time (history), discovery of science and ideology. Modern ideas are often confronted by the classic idea. In the modern world, according to Nasaruddin Umar, the law becomes one of living system in society. ${ }^{20}$

In answering the currents of modernity, there are three fiqh ijtihad paradigms: first, the classical paradigm is ijtihad thought which sought to answer the problems of the modernity with textual interpretation paradigm (read: manhaj lughawi), so that the present reality is measured with the law in the past. Secondly, the modern paradigm is ijtihad thought that seeks to explore the meaning of figh message (read: manhaj maqasidi), known as maqasid alShari'ah ${ }^{21}$ to achieve the public benefit (al-maslahah al-'amma) in addressing the problems of modernity. Third, the secular paradigm that says that passages of fiqh has no relevance to modern life. ${ }^{22}$

In general, Imam al-Haramain, 'Abd al-Malik Abd Allah ibn Yusuf al-Juwaini, (died $478 \mathrm{H}$ ), known as the maqasid figures through his work al-Burhan described the formulation of five main things (al-ushul al-khamsah) which must be protected, so that the author, in this writing, remains grounded in that al-ushul khamsah not on the concept of maqasid al-Shari'ah Abd alMajid al-Najjar. ${ }^{23}$ Meanwhile, the maqasid al-Shari'ah (law purposes) in the development of the law is to ensure the maintenance of five major points, namely hifdz al-din (maintaining the religion), hifdz al-'aql (maintaining the mind), hifdz al-nafs (maintaining the soul), hifdz al-'ird (maintaining the honor), and hifdz al-mal (maintaining the property). ${ }^{24}$

\footnotetext{
${ }^{18}$ Yûsuf al-Qardlâwî, Madkhal li Dirâsah al-Syarî̀'ah al-Islâmiyyah (Kairo: Maktabah Wahbah, 2001), p. 21; Moh Dahlan, Epistemologi Hukum Islam: Studi Atas Pemikiran Abdullahi Ahmed An-Na'im (Yogyakarta: Doctoral Thesis of UIN Sunan Kalijaga, 2006), pp. 73-74.

${ }^{19}$ According to Imam al-Thûfî, texts of laws often lead to disagreements, while maslahah can lead to common understanding. Abdul Wahab Khallaf, Ilmu Ushul Fiqh (Tt: Ttp, 1978), p.197; Wahbah al-Zukhailî, Ushûl al-Fiqh alIslâmî Chapter II, (Beirut: Dâr al-Fikr, 1986), pp. 803-806 and 821-822; Ibrahim Hosen, "Some Notes About Reactualizing Islamic Law", in Muhamad Wahyuni Nafis et al. (eds.), Kontekstualisasi Ajaran Islam 70 Tahun Prof. Dr. H. Munawir Sjadzali, M.A. (Jakarta: Paramadina and IPHI, 1995), pp. 253-257.

${ }^{20}$ Nasarudin Umar, "The concept of Modern Law: A Perspective of Indonesian-ness, Legal System Integration of Religion and National Legal System", in Jurnal Walisongo, Volume 22, No. 1, May 2014, p. 161;

http://journal.walisongo.ac.id/index.php/walisongo/article/download/263/244, retrieved on September $19^{\text {th }}$ 2016

${ }^{21}$ Abdul Wahab Khallaf, Ilmu Ushul Fiqh..., p. 197.

22 James Norman Dalrymple Anderson, Hukum Islam di Dunia Modern, trans. Machnun Husein (Surabaya: CV. Amrpress, 1991), p. 91: see Syamsuri, “Membangun Maqasid Al-Shari'ah Melalui Al-Usuhl Al-Khamsah; Studi Kritis Terhadap Konsep Al-Ghazali Dan 'Abd Al Majid Al-Najjar", Kumpulan Makalah Mata Kuliah Reading Arabic Texts Program Doktoral Pascasarjana UIN Sunan Ampel Surabaya 2016, p. 2.

23 The concept of 'Abd Al-Majid Al-Najjar was not used since this study focused on nurturing aspect of religion, which is then followed by other aspects as part of its implications. See 'Abd al-Majid al-Najjar, Maqasid al-Syari'ah bi Ab'ad Jadidah (Beirut: Dar al-Gharb al-Islami, 2008): Syamsuri, "Membangun Maqasid Al-Shari'ah Melalui AlUsuhl Al-Khamsah; Studi Kritis Terhadap Konsep Al-Ghazali Dan 'Abd Al Majid Al-Najjar”, Kumpulan Makalah Mata Kuliah Reading Arabic Texts Program Doktoral Pascasarjana UIN Sunan Ampel Surabaya 2016, p. 75 and 79.

${ }^{24}$ Abdul Wahab Khallaf, Ilmu Ushul Fiqh...., pp. 197-198 and 200-201; see also Muhammad Abu Zahrah, Ushul Fiqih, trans. Saifullah Ma'sum, (Jakarta: Pustaka Firdaus, 1997).
} 


\section{MADJID INTELLECTUAL HISTORY}

Prof. Dr. H Nurcholish Madjid was born in a small village named Mojoanyar, Jombang, East Java, March 17th 1939 . As his father's track record, Abdul Madjid, he also went through public school known as Sekolah Rakyat (SR) in the morning and in the afternoon he studied in Madrasah until his graduation with good achievement. In his fourteen, Madjid continued his education at Darul Ulum Islamic boarding school Jombang Rejoso with remarkable achievements. Nevertheless, he run "nyantri" (the way of life of Islamic boarding school student) at the boarding school for only two years just because he was aware of his father's position was still active in the Masyumi party. For this reasons, then, his father moved him to Gontor modern Islamic boarding school. It is a dynamic school where students do not only learn the classical sciences, but also modern sciences and its foreign language. In 1961, Madjid moved to Jakarta and studied at the Faculty of Adab, Department of Arabic and Islamic Cultural History, IAIN Syarif Hidayatullah. In 1978, he pursued his Ph.D in Chicago University under the guidance of Fazlur Rahman focusing theology with a dissertation entitled: Ibn Taymiyya on Kalam and Philosophy: A Problem of Reason and Revelation in Islam and he graduated with Cum Laude predicate in $1984 .{ }^{25}$

As a student of modern Gontor, M Amin Abdullah admitted that Gontor Modern Islamic boarding school of Ponorogo has provided supplies for Madjid to associate himself, further, to the centers of the world through foreign language ability even he had corresponded with foreign embassies or international institutions to obtain reading materials. His awareness in reading extensive reference opens a new consciousness structure called imagined communities. ${ }^{26}$

As an activity of the Islamic Students Association (HMI), Majdid had served as Chairman of HMI for two periods that made he has a special status in HMI. Therefore, Madjid is not only able to digest various information and ideas developed universally, but also capable in reproducing new system and fresh ideas. Then, it made his position is unsurpassable in HMI. ${ }^{27}$

As a theologian, Madjid introduced his main idea. It is an inclusive theology that aims to understand the message of God and the nature of religious because it is believed that there is similarity between the teachings of one scripture with other scriptures, (the Bible, the Torah, the Psalms, and the Qur'an), which rests on a "common ground", "common platform", or Sawa' sentence in Qur'an term. (QS: 3: 64). ${ }^{28}$ In the Islamic theology context, Madjid's secularization movement is basically to strengthen the purpose of monotheism, polytheism eradication, and rejecting secularism. ${ }^{29}$ However, in this case, Madjid does not stand alone, but he is also influenced by theological thinking of Fazlur Rahman, ${ }^{30}$ therefore, Madjid perceives world reality positively. ${ }^{31}$

\footnotetext{
25 Greg Barton, Gagasan Islam Liberal di Indonesia...., pp. 72-75, 77 and 85.

26 M Amin Abdullah, Sumbangan Nurcholish Madjid atas Perkembangan Pemikiran Islam Indonesia, http://nurcholishmadjid.net/?page=news\&action=view\&id=64, retrieved on September 19 th 2016. 27 M Amin Abdullah, Sumbangan Nurcholish Madjid atas Perkembangan Pemikiran Islam Indonesia, http://nurcholishmadjid.net/?page=news\&action=view\&id=64, retrieved on September 19th 2016.

${ }_{28}$ Maria Ulfa, "Observing religion inclusivism of Nurcholish Madjid”, Jurnal KALIMAH, Vol. 11, No. 2, September 2013, p. 239; see also Sukidi, Teologi Inklusif Cak Nur, (Jakarta: Kompas, 2001).

${ }^{29}$ M Dawam Rahardjo, "Islam dan Modernisasi: Catatan atas Paham Sekularisasi Nurcholish Madjid" dalam Madjid, Islam Kemodernan...., p. 27 and 187-218.

30 Falur Rahman supports the reform of tasawuf, from passive zuhud to active zuhud. Fazlur Rahman, Islam, trans. Ahsin Muhammad, (Bandung: Pustaka, 1984).

31 Barton, Gagasan Islam Liberal di Indonesia...., p. 108.
} 
As a reformer of Islam, Masjid introduced ideas of modernization as rationalization efforts, not rationalism, ${ }^{32}$ which is supported by the moral dimension based on the notion of faith to Allah, not Westernization. According to Madjid, something is called modern if it is rational, scientific, and in conformity with the laws. In this case, modernization is an absolute necessity as the implementation of the orders of Allah to seek the truth and the efficiency of thought and work to achieve maximum happiness or prosperous living. ${ }^{33}$ According to him, opening the door of ijtihad in the early 20th century produced unsatisfactory modernism. Thus, Madjid thought that opening the doors of ijtihad in the $21^{\text {st }}$ century should construct an inclusive and universal Islamic thinking. ${ }^{34}$

As an innovator in modern fiqh, on $28^{\text {th }}$ October 1972, Madjid wrote a paper entitled "Renewal Thought Perspective in Islam", which was delivered on the Jakarta Literary Arts Council Occasion in Jakarta that explore fiqh issues as a codification of the work of Islamic scholars in the second century and The third Hijriyah. ${ }^{35}$ Madjid academic anxiety as a reformer of fiqh that get matured with his work published in Budhy Munawar-Rachman (ed.), Contextualization of Islamic doctrine in History, Jakarta: Paramadina, 1995, some of those article entitled; (a) "Contemporary Views of Fiqh: Assessing Problems of Islamic law in the Modern Age", which suggests the importance of considering the problem of continuity and change in doing fiqh ijtihad along with the importance of considering maslahah as a basis for the development of Islamic law / fiqh; (b) "Early History of forming and Standardization of Islamic law" that explores the fundamentals of fiqh that has been placed in the Mecca period and then during the Madina period; (c) "Syarah and Hasyiyah Tradition in Fiqh and Stagnation of Islamic Legal Thought Problems" that explores issues of Islamic law system of thought-which later known as Fiqh, since the prophet's (PBUH) companions period, tabi'in period, tabi'it tabi'in period, and imam madzhab period - is the dynamics and creativity; (d) "The concept of Asbab al-Nuzul: Its Relevance toward Historical view upon Specific Aspects of Religious Doctrine" reviewing almaslahah al-'amma (public interest) as a basis for consideration in issuing legal decisions as well as the practices done by Umar. Even though, it disputes the verses of the Qur'an and the practice of prophet's (PBUH) companions. In this last article, Madjid stated:

"The second caliph's action that violates Scripture passages, also violates what most of the companions of the Prophet (PBUH). Because, beside Hudhayfah, there are several prominent companions of the Prophet who was married to a ahl al-Kitab woman, such as Uthman bin Affan, the third caliph, who was married to Arab Christian women, Na'ilah al-Kalbiyah, and Talhah ibn UbaydAllah who got married with a Jewish woman from Syam. But .... Umar did not ban it except after seeing the things that are less favorable to the Islamic community". ${ }^{36}$

\footnotetext{
32 According to Madjid, rationalism denies the truth of revelation as a medium for reaching the truth, and only recognizes ratio. Rationality is a method to achieve an accurate understanding and assessment of the problem and its solution. Rationalization is the process of using that method. Madjid, Islam Kemodernan...., pp. 219-220.

33 It is basically associated with the creation of nature with truth (Q.S. 16: 3, 38: 27), sunnatullah (Q.S.7:54, 25:2), harmony and kindness (Q.S. 21:7, 67: 3), observing and examining the laws that exist in creation of Allah swt (Q.S. 10: 101), the creation of nature for human's benefits and its welfare (Q.S.45: 13), commands to use reasoning and restrictions to hamper the development of thinking (Q.S. 2: 170, 43: 22-25). Madjid, Islam Kemodernan...., pp. 172173 and 187.

${ }^{34}$ M. Dawam Rahardjo, “Gerakan Islam Kultural Paramadina: Fundamentalisme Agama dan Masa Depan Keislaman dan Keindonesiaan", http://nurcholishmadjid.net/index.php?page=news\&action=view\&id=62, retrieved on September 19th 2016)

35 See this paper in Madjid, Islam Kemodernan..., p. 255 and 325.

36 Madjid, "Konsep Asbab al-Nuzul: Relevansinya bagi Pandangan Historis Segi-Segi Tertentu Ajaran Keagamaan" in Budhy Munawar-Rachman (ed.), Kontekstualisasi Doktrin..., p. 33.
} 
As an innovator in modern fiqh, Madjid is also influenced by the thought of the ijtihad concept from Fazlur Rahman's double movement, ${ }^{37}$ consequently, secularization, in this case, could be interpreted as desecration of the results of past fiqh thinking that was sacred and sacred things such as muhkamat passages used as the primary base in the development of the fiqh law. Thus, content of past fiqh used as references in developing modern fiqh paradigm now, not vice versa.

\section{FIQH MODERNITY PROBLEM IN INDONESIA}

In general, sociology scientists have been predicting the death of the religion. This prediction was built on two fundamental arguments: first, modern science is assumed to have been able to resolve the problems of human life. Second, modern science has provided the convenience of humanity with all its affluence and luxury. ${ }^{38}$ It is also reinforced by the nature of modern science that has the spirit of hostility to the existence of religion. ${ }^{39}$

The views of that modern science come from the scientific paradigm of Auguste Comte (17981857) who argued that social evolution will start from the theological stage, the metaphysical stage until the positivistic stage. ${ }^{40}$ Entering the 20th century, Sigmund Freud, a world psychologist, published his work entitled The Future of Illusion predicting that religion will end because religion is judged only as human's desire. ${ }^{41}$ This is the foundation of western secular-modernist's thought who wants the separation of religion and worldly things, and the liberation of religious blasphemy. ${ }^{42}$

Modern culture with its biological children (secularism) that puts the profession and other rational elements as the main actor has eliminated the religious authorities in controlling social and political institutions. As the result, religion is considered just as ancient heritage of the past. In addition, the freedom inherited by modern culture also brings limitless cultural stream..$^{43}$

Responding the modern culture, Muhammad Abduh stated that it is not enough if Muslim just simply goes back to the original teachings of Qur'an and Sunnah as recommended by Muhammad Abd al-Wahab, but the original teaching must adapt to modern culture to open the doors of moden ijtihad and, at the same time, eradicate the dogmatic attitude, heresy, and fatalist. 44

Muhammad Rashid Ridla is the successor of the modern ijtihad initiator and he is also combating bid'ah and taklid inspired by Muhammad Abduh. Although Ridia is not as liberal as

\footnotetext{
37 Fazlur Rahman, Islam and Modernity: Transformation of an Intellectual Tradition, (Chicago: The University of Chicago Press, 1982): Barton, Gagasan Islam Liberal di Indonesia...., p. 108.

38 Rodli Makmun, “Agama di Tengah Jaring-jaring Dunia Modern”, in Religió: Jurnal Studi Agama-agama, Volume 3, No. 2, September 2013, pp. 189-190, see

also http://religio.uinsby.ac.id/index.php/religio/article/download/77/69, retrieved on September 19 th 2016.

${ }^{39}$ Abdurrahman Wahid, "Dialog Agama dan Masalah Pendangkalan Agama", in Komaruddin Hidayat and Ahmad Gaus AF, ed, Passing Over: Melintasi Batas Agama (Jakarta: Gramedia, 2001), pp. 53-54.

40 Makmun, “Agama di Tengah Jaring-jaring Dunia Modern”, in Religió....,pp. 190-191.

41 Makmun, “Agama di Tengah Jaring-jaring Dunia Modern”, in Religió..., p. 191.

42 Makmun, “Agama di Tengah Jaring-jaring Dunia Modern”, in Religió..., p. 193.

${ }^{43}$ In this case, Madjid did critique and even denied the existence of liberalism, secularism, rationalism, individualism, capitalism, humanism, pragmatism and atheism. Makmun, "Agama di Tengah Jaring-jaring Dunia Modern”, in Religió...,pp.194-195: M Dawam Rahardjo, "Islam dan Modernisasi: Catatan atas Paham Sekularisasi Nurcholish Madjid" in Madjid, Islam Kemodernan..., pp. 27-28.

44 Modern science which is a lot based on natural law (sunnatullah) does not conflict with true Islam. Nasution, Pembaruan dalam Islam..., pp. 54-57.
} 
his teachers in the use of reasoning problems, Ridla explained that ijtihad as a dynamic effort in addressing the problem of life, but not to worship. ${ }^{45}$

Mustafa Kemal as a nationalist and admirer of Western civilization put forward the idea of the separation of state from religion. According to him, Turkey will only go forward if it follows the whole of Western civilization. However, Mustafa Kemal's secularization does not deny the religion, but it centered on clerical rule in state affairs and politics. ${ }^{46}$

Sayyed Amir Ali in his work, "The Spirit of Islam" stated that Islam is a religion that is comfortable with the mind, bringing progress and development of science while the decline of Muslims is caused by the notion of the closing of ijtihad door and the spread of the taklid culture in the ninth century. ${ }^{47}$

Muhammad Iqbal is one of the reformers from Pakistan who declared that the door of ijtihad is never closed and Islamic law is not static, but dynamic because the Qur'an advocates the use of mind to read the signs of nature. Therefore, the civilization of Western capitalism is not a reference in modern ijtihad updates and the thing that needs to be taken from the Western civilization is only the science. 48

In the context of modern life, Madjid think that modern era has a different nature and character from the agrarian age. Although Islam is derived from the culture in an agrarian age, it continues to experience rapid triumph for their dynamic relationship between modern dogmas for the science of divinity, including the fiqh principles, which is not as complicated as Christianity. 49

And due to the factors history as the height of the agrarian urban, Islam has the potential to be the heir of the most fortunate of modern times. Moreover, Islam can be progressors and developers in the future because the elements of basic modern times are not a new thing in Muslims life. If we take the events of the Christian Inquisition in facing the science, there is, practically, no similar thing in Islam. History proves how problematic the relationship between Christian dogma and modernity, the science. In Islam, this problematic situation may not exist at all.50

Likewise, social reality of Indonesian faces the complex problem of modernity in the beginning of the establishment of the foundations of the state. The problem cannot be separated from the plurality in all aspects, whether racial, ethnic, language, skin color or religion. Plurality of religious life also affects the plurality of social interests and political. Therefore, since the beginning of the establishment of the Republic of Indonesia, it has appeared diverse interests and views in building the state ideology. There was a desire to create it based on certain religion, Islamic law/fiqh, and there was also a desire of using secular ideologies. From that

\footnotetext{
45 According to Abduh, the texts of Qur'an that mention God has hands and the seat should be given the implied interpretation, while Ridla still interprets the throne, but the throne of Allah is different from human throne. Nasution, Pembaruan dalam Islam..., pp. 65-67.

46 Nasution, Pembaruan dalam Islam..., pp. 140-145.

47 Nasution, Pembaruan dalam Islam..., pp. 176-181.

48 Nasution, Pembaruan dalam Islam..., pp. 184-187.

${ }^{49}$ Madjid, "Pandangan Kontemporer tentang Fiqh: Telaah Problematika hukum Islam di Zaman Modern”, in Budhy Munawar-Rachman (ed.), Kontekstualisasi Doktrin...,pp. 378-379.

50 Madjid, "Pandangan Kontemporer tentang Fiqh: Telaah Problematika hukum Islam di Zaman Modern”, in Budhy Munawar-Rachman (ed.), Kontekstualisasi Doktrin...,pp. 379-380.
} 
debate, the founders of Indonesia decided the best and accommodative solutions in form of inclusive and universal ideology and constitution, the Pancasila and the Constitution of the Republic of Indonesia in 1945 which is not secular, and also does not embrace the ideology of particular religion, but it can accommodate all of them. ${ }^{51}$

Ideologically, the values of Islam affect the formulation of the Pancasila values, i.e. the terminology of fair, civilized, people, wisdom, discussion, representatives, and expressions of ulama: ra'sul hikma al-masyurah (the base of wisdom is discussion). ${ }^{52}$ Meanwhile, the national legal system in Indonesia has made Islamic law/fiqh as a source of national law legally. ${ }^{53}$ In line with the nature of national laws, fiqh does not only refer to the legal normative sources, Qur'an and Sunnah, but also provide space for other sources such as the 'urf (Q.S. al-Ma'idah [5]: 3). ${ }^{54}$ Therefore, the Indonesian legal system applied today that embraces mixed system (according to Ahmad Ali) is derived from a customary law system, Islamic law and Western law that became a basic element in the formation of law in Indonesia. According to Eric L. Rischard, the Indonesian legal system is included in the Far East Law that embraces a complex legal system that combines civil law, common law and Islamic law. This legal system has a harmonious characteristic. ${ }^{5}$

\section{MADJID'S MODERN FIQH IJTIHAD PARADIGM}

Literally, ijtihad is the mobilization of all the ability to do all the hard stuff. Based on prophet's friends' point of view, ijtihad is a research and thought that trying to get a closer view of the law to Qur'an and the Sunnah whether it is obtained from the nearest known of passages understanding known as qiyas or passages purposes known as maslahah. According to fiqh scholars, ijtihad is effort done by expert to gain a "dhann" level understanding of syara' law. ${ }^{56}$

Historically, ijtihad has been done by the Prophet Muhammad (PBUH) in some of the events: first, the Prophet never enacted laws for himself specifically with unlawful provisions for the benefit of the public, but Allah then admonished him (Q.S. at-Tahrim [66]: 1- 2). Second, the Prophet did ijtihad in positioning troops at the Battle of Badr. When al-Habab al-Munzir asked the Prophet, is the deployment of the troop God's command? The Prophet replied: "It is the opinion, the war strategy". ${ }^{57}$

At the time of prophet's companions, ijtihad movement was promoted as done Abu Bakar assisted by Umar ibn al-Khattab to devise a method of ijtihad. Ijtihad of the prophet's companions could not be separated from the demands of public benefit interlinked with the time development. Umar also performed a dynamic ijtihad with some new breakthrough, for example, restrictions for prophet's companions to get married with the Jews and Christians,

\footnotetext{
51 John L. Esposito and John 0. Voll, Demokrasi di Negara-negara Muslim; Problem dan Prospek, trans. Rahmani Astuti (Bandung: Mizan, 1998); Abdurrahman Wahid, "Islam di Asia Tenggara”, in Abu Zahra ed. Politik Demi Tuhan, (Jakarta: Pustaka Hidaya, 1999), pp. 195-197.

52 Madjid, Islam Kemodernan...., pp. 68-69.

53 One proof of Islamic law or fiqh to be one source of national laws is the "Law of the Republic of Indonesia No. 38 in 1999 on Management of Zakat" (Lembaran Negara Republik Indonesia Tahun 1999 Nomor 164 and Tambahan Lembaran Negara Republik Indonesia Nomor 3885)

${ }^{54}$ Abdurrahman Wahid, Islamku, Islam Anda, Islam Kita (Jakarta: The Wahid Institute, 2006), p. 309.

55 Nasarudin Umar, "Konsep Hukum Modern: Suatu Perspektif Keindonesiaan, Integrasi Sistem Hukum Agama dan Sistem Hukum Nasional”, in Walisongo, Volume 22, No. 1, May 2014, p. 158; http://journal.walisongo.ac.id/index.php/walisongo/article/download/263/244, retrieved on September $19^{\text {th }}$ 2016; see also Achmad Ali, Menguak Teori Hukum dan Teori Peradilan, (Jakarta: Kencana, 2009), pp. $203-206$. ${ }^{56}$ KH Ibrahim Hosen, "Taqlid dan Ijtihad: Beberapa Pengertian Dasar", in Budhy Munawar-Rachman (ed.), Kontekstualisasi Doktrin ...., pp. 319-320.

57 Dedi Ismatullah, Sejarah Sosial Hukum Islam, (Bandung: CV Pustaka Setia, 2011), pp. 180-181.
} 
whereas Qur'an allows it. This shows that Umar's ijtihad in some cases was not based on the God's decree, but by his maqasid al-syari'ah. ${ }^{58}$ Similar to ijtihad done by fiqh experts in the modern world, it became the basis for ulamas to agree on the rules: "Islamic law/fiqh changes are caused by the changing of times". 59

In answering the modern world, there are a number of Muslim thinkers who reinterpreted the texts of fiqh. Among them is Abdullah Ahmed An-Na'im or An-Na'im, a Sundanese reformer, he reformed the Islamic law (fiqh) in addressing the modernity problem by applying evolutionary methods of legislation Makkiyah surah that has been deleted with madaniyah verses changed by the reverse, because the Makkiyah verses has inclusive universal values. ${ }^{60}$ That ijtihad paradigm is different from the ulamas' ijtihad paradigm in general, for example Manna Khalil al-Qattan. ${ }^{61}$ In line with An-Na'im, Masdar F. Mas'udi also thinks that the passages of the Quran and al-Sunnah that have inclusive and universal values called as muhkamat passage, the passages explaining the teachings principal, while the Qur'an verses and al-Sunnah explaining the technical-practical teachings which is called as mutashabihat passage. ${ }^{62}$

In accordance with Masdar's thinking, Madjid suggests that his modern ijtihad paradigm is based on muhkamat passages, not mutashabihat passages. Renewal in the form of a paradigm shift from the classic ijtihad paradigm that has a textual and conservative tendency into the modern ijtihad paradigm must be done, and even must be an absolute necessity in order to implement the command of Allah to seek the truth and the efficiency of thinking and working to achieve maximum happiness and prosperous life. ${ }^{63}$ Therefore, ijtihad paradigm of the $21^{\text {st }}$ century must produce legal formulations of inclusive and universal fiqh. ${ }^{64}$

In doing the ijtihad, Madjid requires no reform movement or reinvigorate of fiqh passage understanding, in this case, inspired by the paradigm of Umar Ibn Khattab's ijtihad who considers "benefit and see the meanings that become the pivot of the Islamic law establishment" and also detracted by paradigm of modern Muhammad Abduh's ijtihad that "understands ijtihad in a broad sense as free research, islamic law and norms, and about what is the best right now". ${ }^{65}$ Likewise, the effect of the Fazlur Rahman's double interpretation paradigm is visible in Majdid's thought:

\footnotetext{
58 Madjid, "Konsep Asbab al-Nuzul: Relevansinya bagi Pandangan Historis Segi-Segi Tertentu Ajaran Keagamaan" in Budhy Munawar-Rachman (ed.), Kontekstualisasi Doktrin...,p. 31

59 Madjid, "Pergeseran Pengertian "Sunnah ke Hadis": Implikasinya dalam Pengembangan Syariah", in Budhy Munawar-Rachman (ed.), Kontekstualisasi Doktrin...,p. 221.

${ }^{60}$ Mahmoud Muhammed Taha, The Second Message of Islam, trans. Abdullahi Ahmed An-Na'im (New York: Syracuse University Press, 1987), p. 28; Abdullahi Ahmed An-Na'im, "Mahmoud Muhammed Taha and The Crisis In Islamic Law Reform: Implications for Interreligious Relations", Jurnal of Ecumenical Studies, 25: 1, Winter 1988, pp. 15-16; An-Na'im, Toward an Islamic Reformation ...., p. 52.

61 Manna Khalil al-Qattan, Mabahis fi al-Ulum al-Qur'an (Publisher: Masyurat al-Asr al-Hadits, III, 1973), pp. 326327.

62 Masdar F. Mas'udi, Islam \& Hak-hak Reproduksi Perempuan, (Bandung: Mizan, 1997), pp. 50-51.

63 It is basically associated with the creation of nature with truth (Q.S. 16: 3, 38: 27), sunnatullah (Q.S.7:54, 25:2), harmony and kindness (Q.S. 21:7, 67: 3), observing and examining the laws that exist in creation of Allah swt (Q.S. 10: 101), the creation of nature for human's benefits and its welfare (Q.S.45: 13), commands to use reasoning and restrictions to hamper the development of thinking (Q.S. 2: 170, 43: 22-25). Madjid, Islam Kemodernan...., pp. 172173 and 187

64 M. Dawam Rahardjo, “Gerakan Islam Kultural Paramadina: Fundamentalisme Agama dan Masa sepan Keislaman dan Keindonesiaan”, http://nurcholishmadjid.net/index.php?page=news\&action=view\&id=62, retrieved on September 19th 2016)

65 Madjid, "Taqlid dan Ijtihad: Masalah Kontinuitas dan Kreativitas dalam Memahami Pesan Agama”, in Budhy Munawar-Rachman (ed.), Kontekstualisasi Doktrin...,pp. 346-347.
} 
"While what is in the Qur'an, even it is spoken in terms of space and time or experience of the Prophet, the teaching of moral behind the story is always dynamic so it can be easily lifted to a high level of generality, thus it is universal worth. Because of the Sunnah of the Prophet was not limited only to the hadith, although sahhih hadith is included as sunnah".66

In this case, Madjid explained that a mujtahid or intellectuals must have a deep knowledge of Islam and must know the history of the past to "be able to be more prudent in the future. God says: Actually, in the history of the people in the past, there is a lesson for those who are rational" (Q.S.12:111). ${ }^{67}$ This Qur'an's verse give a lesson telling that to understand the texts of laws we must understand its historical reality to explore its spirit and intent, so inclusive and universal of message of the law can be formulated in the present life and future.

Here, there is a movement to go back to the reason behind the existence of the fiqh in the past and then pulled its universal message and formulated to be brought back to the present in order to answer the actual problems. As for the attempt to return to the present situation remains guided by "the parametric things in the holy book known as al-muhkamat (instructions with clear meaning), which is also referred to as the basic principles or main teachings of Scripture (umm al-Kitab), as opposed to metaphorical guidance, allegorical and interpretative (mutasyabihat)" ${ }^{68}$

Likewise An-Na'im proposes that the Qur'an verses and Sunnah that have inclusive and universal values are muhkamat, while the technical-practical is mutasyabihat. ${ }^{9}$ The effort to preserve the inclussive - universal values (Q.S. al-Fath: 48: 29), Abdurrahman Wahid suggested the need for adhering to the principle of inclussive - universal legal development of fiqh, so the law of fiqh can develop harmoniously with the development of space and time (shālihun likulli zamānin wa makānin). ${ }^{70}$

Therefore, Madjid suggests modern ijtihad paradigm-which cites the opinion of Umar ibn alKhattab that adheres the principles of public benefit - the principles are as follows: ${ }^{71}$ first, the principle of authenticity expressed by Umar that "any decisions regarding a case must first be sought or based on Qur'an and Sunnah". Second is the principle of the development of the the Qur'an and Sunnah inclussive - universal basic values. It is done to accommodate the things that have not been explicitly described through analogical reasoning (qiyas)..$^{72}$ Third, the

\footnotetext{
66 Madjid, "Pergeseran Pengertian "Sunnah ke Hadis": Implikasinya dalam Pengembangan Syariah", in Budhy Munawar-Rachman (ed.), Kontekstualisasi Doktrin...,p. 210 and 214.

67 Madjid, Islam Kemodernan...., p. 192.

68 Madjid, "Taqlid dan Ijtihad: Masalah Kontinuitas dan Kreativitas dalam Memahami Pesan Agama", in Budhy Munawar-Rachman (ed.), Kontekstualisasi Doktrin...,p. 341.

${ }^{69}$ Compare with John L. Esposito dan John O. Voll's work, Demokrasi di Negara-negara Muslim; Problem dan Prospek, trans. Rahmani Astuti, (Bandung: Mizan, 1998).

70 Wahid, "Dialog dan Masalah Pendangkalan Agama..., p. 53; Wahid, Islamku, Islam Anda, Islam Kita..., p. 123.

${ }^{71}$ According to Majdid, "Prophet's understanding toward God's message or revelation and His example in doing so established a prophetic "tradition" or "sunnah" (al-Sunnah al-Nabawiyah). While tradition is a form of reportage or narrative about what caused the Prophet. Madjid, "Pergeseran Pengertian "Sunnah ke Hadis": Implikasinya dalam Pengembangan Syariah”, in Budhy Munawar-Rachman (ed.), Kontekstualisasi Doktrin...,p. 210 and 214.

72 In answer to modernity, Madjid says that something is said to be modern now, will likely be conservative (not modern anymore) in the future. While absolute modern is an absolutely true, Allah. Thus, modernity is a process of finding the truth relative to the absolute truth, namely God Almighty. The ultimate purpose of human life is the absolute truth, namely God himself. This thinking is in accordance with the spirit of the rule of law: taghayyurul ahkam bitaghayyuril azman. Madjid, Islam Kemodernan...., p. 174: Nurcholish Madjid, "Pergeseran Pengertian “
} 
principle of the decision cancellation of lawsuits that is not well-suited to the factual reality, so that ijtihad is necessary to find a new legal decision. In Qur'an, this is known as nasikhmansukh. ${ }^{73}$ Fourth, the firmness principle in determining the legal decisions that have not been regulated explicitly in the Qur'an and Sunnah, but it is necessary to create the primary benefit. Fifth is the sincerity principle in making the fiqh legal decisions. ${ }^{74}$

In the inclusive and universal fiqh formulation, Madjid stated that ijtihad should be done to achieve inclusive and universal legal values, because every scripture, basically, has similarities between one scripture with other scriptures in the construction of the public benefit. All scripture (the Bible, the Torah, the Psalms, and the Qur'an) are the message of God has a universal and unity characteristic, inherited the Abrahamic Religion. The Word of God becomes a source of law which has the same truth value as the basic because the basic of religions is one and similar one another, having one "common ground and common platform". In Qur'an, it is known as Sawa' passage (QS: 3: 64). ${ }^{75}$ Therefore, fiqh ijtihad must be based on legal grounds (God, the legis ration) by, always, paying attention to the similarities with the public interest (al-maslahah al-'amma) containing inclusive - universal values and regarding its implementation in building a public benefit and Indonesia. ${ }^{76}$ Borrowing Syamsuri's thought, muhkamat passages of modern ijtihad paradigm will render maslahah qath'iyah, while mutashabihat passages of classic ijtihad paradigm will bear maslahah dzanniyah. ${ }^{77}$

Sunnah ke Hadis": Implikasinya dalam Pengembangan Syariah", in Budhy Munawar-Rachman (ed.),

Kontekstualisasi Doktrin...,p. 221.

73 Imam asy-Syafii credited with formulating syariah by historical considerations, so that scholars agree especially with the changing times are reflected in the following rules: taghayyurul ahkam bitaghayyuril azman (law changing by time changing) and la yungkaru taghayyurul ahkam bi taghayyuril azman (it is undeniable that change in the law by changing times). Madjid, "Pergeseran Pengertian "Sunnah ke Hadis": Implikasinya dalam Pengembangan Syariah”, in Budhy Munawar-Rachman (ed.), Kontekstualisasi Doktrin...,p. 221.

${ }^{74}$ Madjid, "Taqlid dan Ijtihad: Masalah Kontinuitas dan Kreativitas dalam Memahami Pesan Agama”, in Budhy Munawar-Rachman (ed.), Kontekstualisasi Doktrin...,pp. 339-341.

75 Maria Ulfa, "Mencermati Inklusivisme Agama Nurcholish Madjid", Jurnal KALIMAH, Vol. 11, No. 2, September 2013, p. 239; see also http://ejournal.unida.gontor.ac.id/index.php/kalimah/article/download/94/84, retrieved on September 19th 2016; compare to Sukidi, Teologi Inklusif Cak Nur, (Jakarta: Kompas, 2001).

76 Madjid, "Konsep Asbab al-Nuzul: Relevansinya bagi Pandangan Historis Segi-Segi Tertentu Ajaran Keagamaan" in Budhy Munawar-Rachman (ed.), Kontekstualisasi Doktrin..., p. 34.

77 Syamsuri, "Membangun Maqasid Al-Shari'ah Melalui Al-Usuhl Al-Khamsah; Studi Kritis Terhadap Konsep Al-Ghazali Dan 'Abd Al Majid Al-Najjar”, Kumpulan Makalah Mata Kuliah Reading Arabic Texts Program Doktoral Pascasarjana UIN Sunan Ampel Surabaya 2016, p. 78. 
Table I

Fiqh Ijtihad Paradigm

\begin{tabular}{|l|l|l|l|}
\hline No & Base of Ijtihad & $\begin{array}{l}\text { Classic Fiqh Ijtihad } \\
\text { Paradigm }\end{array}$ & $\begin{array}{l}\text { Modern Fiqh Ijtihad } \\
\text { Paradigm }\end{array}$ \\
\hline 01 & Reference & $\begin{array}{l}\text { Muhkam is technical } \\
- \text { practical verses }\end{array}$ & $\begin{array}{l}\text { Muhkam is inclusive } \\
- \text { universal verses }\end{array}$ \\
\cline { 3 - 4 } & & $\begin{array}{l}\text { Mutasyabih is } \\
\text { universal global } \\
\text { verses }\end{array}$ & $\begin{array}{l}\text { Mutasyabih } \\
\text { technical - practical } \\
\text { verses }\end{array}$ \\
\hline 02 & Method & Textual Paradigma & $\begin{array}{l}\text { Contextual } \\
\text { Paradigma }\end{array}$ \\
\hline 03 & Possibility & $\begin{array}{l}\text { Conservative } \\
\text { formalistic }\end{array}$ & $\begin{array}{l}\text { Dynamic- } \\
\text { Substancialistic }\end{array}$ \\
\hline
\end{tabular}

\section{MADJID'S MODERN FIQH PARADIGM}

Responding the modernity, Madjid suggests that modern culture is identic with advances in all aspects of human life, both in the culture and industry and science-technology aspects. Basically, they are not contradictive with the fiqh law. With its beneficial principle, fiqh became an inclusive and universal law teaching. Humans should not abandon their Islamic culture in pursuing the development of modern culture, industry, and science-technology. In this case, fiqh can be a principle and guidance in answering the dynamics of the change. ${ }^{78}$ Therefore, whatever the changes that occurs, Muslims can still embrace the fiqh values as their life guidance. ${ }^{79}$

In this context, the Majdid's modern ijtihad paradigm is applied to build a legal modern fiqh provisions as an effort to make a paradigm shift from the paradigm of classic scientific fiqh into inclusive paradigm of modern inclusive - universal fiqh to achieve the benefit of Indonesians. It is happened because the problem of modernity and the public benefit have the similar point of view in answering a various issues in the dynamic future and dynamic not the past. Thus, the principle of "modernization" and "maslahah" have a common goal, the continuous renewal process that fit the humans' needs and it makes fiqh endless but develop side by side with the time to achieve prosperous society which can be seen from positive and negative side in keeping the five main things (al-ushul al-khamsah). ${ }^{80}$ In this case, the authors propose a comparison between the classic fiqh paradigm with the modern fiqh paradigm in Indonesia.

\footnotetext{
78 Madjid expressed his opinion by citing Leonard Binder's thinking as follows: “... it is not necessary to leave any items of an essentially Islam". Madjid, "Pandangan Kontemporer tentang Fiqh: Telaah Problematika hukum Islam di Zaman Modern”, in Budhy Munawar-Rachman (ed.), Kontekstualisasi Doktrin...,pp. 382-383.

${ }^{79} \mathrm{~A}$ famous sociologist, Ernest Gellner, argued that "Islam and modernity that make a Muslim may be more confident". Madjid, "Pandangan Kontemporer tentang Fiqh: Telaah Problematika hukum Islam di Zaman Modern", in Budhy Munawar-Rachman (ed.), Kontekstualisasi Doktrin..., p. 381.

${ }^{80}$ Madjid, Islam Kemodernan..., p. 274; Abdul Wahab Khallaf, Ilmu Ushul Fiqh...., p. 200.
} 
Table II

Classic Fiqh Paradigm 81

\begin{tabular}{|l|l|l|l|}
\hline No & $\begin{array}{l}\text { Al-ushul al- } \\
\text { khamsah }\end{array}$ & \multicolumn{1}{|c|}{ Positive Side } & Negative Side \\
\hline 01 & $\begin{array}{l}\text { Hifdz al-din } \\
\text { (maintaining the } \\
\text { religion }\end{array}$ & Performing Sholat (Prayer) & Forbidding riddah \\
\hline 02 & $\begin{array}{l}\text { Hifdz al-'aql } \\
\text { (maintaining the } \\
\text { mind) }\end{array}$ & Performing Study & Forbidding alcohol \\
\hline 03 & $\begin{array}{l}\text { Hifdz al-nafs } \\
\text { (Maintaining the } \\
\text { soul) }\end{array}$ & Performing qishas & Forbidding unlawful killing \\
\hline 04 & $\begin{array}{l}\text { Hifdz al-'ird } \\
\text { (maintaining the } \\
\text { honor) }\end{array}$ & Performing marriage & Forbidding adultery \\
\hline 05 & $\begin{array}{l}\text { Hifdz al-mal } \\
\text { (Maintaining the } \\
\text { property) }\end{array}$ & Performing buying and selling & Forbidding theft \\
\hline
\end{tabular}

81 Syamsuri, "Membangun Maqasid Al-Shari'ah Melalui Al-Usuhl Al-Khamsah; Studi Kritis Terhadap Konsep Al-Ghazali dan 'Abd Al Majid Al-Najjar", Kumpulan Makalah Mata Kuliah Reading Arabic Texts Program Doktoral Pascasarjana UIN Sunan Ampel Surabaya 2016, p. 80. 
Table III

Modern Fiqh Paradigm in Indonesia

\begin{tabular}{|c|c|c|c|}
\hline No & $\begin{array}{c}\text { Al-ushul al- } \\
\text { khamsah }\end{array}$ & Positive side & Negative side \\
\hline 01 & $\begin{array}{l}\text { Hifdz al-din } \\
\text { (maintaining the } \\
\text { religion }\end{array}$ & $\begin{array}{l}\text { Creating inclusive - universal } \\
\text { theology } \\
\text { Maintaining the relationship to } \\
\text { God and Human } \\
\text { Maintaining Iman and Taqwa } \\
\text { Enforcing tha Syahadah and } \\
\text { secularization } \\
\text { Building a harmonious relation } \\
\text { between religion and nation } \\
\text { Establishing dialogue among } \\
\text { religions }\end{array}$ & $\begin{array}{l}\text { Prohibitting exclusive } \\
\text { conservative theology } \\
\text { Prohibitting worshiping to } \\
\text { others thing except God } \\
\text { Prohobitting syirik } \\
\text { Prohibitting secularism } \\
\text { Prohbitting internal conflict } \\
\text { and inter religious conflict } \\
\text { Prohibiting metaphysics - } \\
\text { animistic view }\end{array}$ \\
\hline 02 & $\begin{array}{l}\text { Hifdz al-'aql } \\
\text { (maintaining the } \\
\text { mind) }\end{array}$ & $\begin{array}{l}\text { Obligation to study and to keep } \\
\text { a healthy mind } \\
\text { Developing rationalization or } \\
\text { ijtihad } \\
\text { Developing the use of mind or } \\
\text { ratio } \\
\text { Building esotericism }\end{array}$ & $\begin{array}{l}\text { Prohibition of alcohol } \\
\text { Rejecting rationalism } \\
\text { Rejecting blind taklid } \\
\text { Rejecting conservatism } \\
\text { Limiting esotericism }\end{array}$ \\
\hline 03 & $\begin{array}{l}\text { Hifdz al-nafs } \\
\text { (Maintaining the } \\
\text { soul) }\end{array}$ & $\begin{array}{l}\text { Keeping the existence of human } \\
\text { right and obligation } \\
\text { Protecting the right and equality } \\
\text { for all mankind }\end{array}$ & $\begin{array}{l}\text { Prohibiting the violation of } \\
\text { right and obligation among } \\
\text { mankind } \\
\text { Performing qishash } \\
\text { Prohibiting violence, killing, } \\
\text { and conflict } \\
\text { Prohibiting discrimination }\end{array}$ \\
\hline 04 & $\begin{array}{l}\text { Hifdz al-'ird } \\
\text { (maintaining the } \\
\text { honor) }\end{array}$ & $\begin{array}{l}\text { Arranging marriage } \\
\text { Maintaining the value and } \\
\text { human dignity } \\
\text { Maintaining the religious } \\
\text { identity as an awareness symbol } \\
\text { and nation awakening in front of } \\
\text { colonialists } \\
\text { Maintaining the confidence, } \\
\text { progressivity and creativity }\end{array}$ & $\begin{array}{l}\text { Prohibiting adultery } \\
\text { Stoning (rajam) for adultery } \\
\text { Prohibiting apology act } \\
\text { Prohibiting inferiority }\end{array}$ \\
\hline 05 & $\begin{array}{l}\text { Hifdz al-mal } \\
\text { (Maintaining the } \\
\text { property) }\end{array}$ & $\begin{array}{l}\text { Working to seek sustenance and } \\
\text { doing mualamah } \\
\text { Solving economy problem } \\
\text { comprehensively } \\
\text { Realizing the values of social } \\
\text { justice, welfare and prosperity }\end{array}$ & $\begin{array}{l}\text { Prohibiting theft } \\
\text { Prohibiting economy problem } \\
\text { partially } \\
\text { Prohibiting injustice and } \\
\text { monopoly }\end{array}$ \\
\hline
\end{tabular}

The description, in the table, in Madjid's modern fiqh paradigm is done by using modern ijtihad paradigm that considers the principle of al-maqasid al-Shari'ah (law purposes) in the development of laws that have five main things (al-usul al-khamsah) as follow: ${ }^{82}$

\section{Maintaning the Religion (Hifdz al-Din)}

Classic fiqh ulama should position the concept of "maintaining the religion" not only understood as apostate ban (out of Islam, and death sentence for apostater) as well as the performing mahdla worshipping, ${ }^{83}$ but it should be more than that. Meanwhile, Madjid thinks that maintaining the religion is how to establish a spiritual relationship between man and God,

82 Abdul Wahab Khallaf, Ilmu Ushul Fiqh...., pp. 197-198 dan 200-201.

${ }^{83}$ Abdul Wahab Khallaf, Ilmu Ushul Fiqh...., p. 200. 
and relationship among men harmoniously. In general, maintaining the religion rests on the maintaining the belief as the core of religion, while the religion core is belief, so life is without the belief is impossible. The right confidence in Islam is the faith to believe in God and the more important thing is the attitude of trusting God. The attitude of appreciation to Allah is known as taqwa. Taqwa is the spirit of divinity in a person who believed. ${ }^{84}$

In faith, there should be no syirik (worshiping others thing except God). Thus, Madjid's idea of secularization is to make things worldly and sacred as they are. Liberating Muslims from various religious surveillance or closed metaphysical world view (e.g. the practice of animistic religion in Indonesia in the past). It is an implementation of the Islamic teachings of faith that in the syahadah: There is no god but Allah and Muhammad is His Messenger. It means that those who have faith are not allowed to worship anything except Allah. Therefore, superstition is prohibited in Islam. ${ }^{85}$ Tauhid is the essence of religions brought by the Prophets from Adam until Prophet Muhammad (Q.S. 21:25). Tauhid is what underlies all righteous deeds and the realization of the ultimate benefit. ${ }^{86}$ Based on the principle of Tauhid (monotheism), Madjid provides the best solution in establishing a harmonious and dynamic relation between religion and state. ${ }^{87}$ Thus, faith, taqwa and sense of divinity are the basis of life and the fundamental guide in "keeping the religion". 88

In order to maintain the religion regarding the relationship among mandkin, Madjid suggests the need of dialogue between religions to seek truth, goodness and public benefit for internal believers and inter-religion. ${ }^{89}$ Therefore, the concept of maintaining religion from Madjid made through interfaith dialogue based on inclusive - universal principles of faith/theology, not based on exclusive-conservative creed. The concept of Madjid's inclusive - universal belief, now, has bear the public benefit and Indonesians, not chaos as alleged by Maria Ulfa. ${ }^{90}$

\section{Maintaining the Mind (Hifdz al-'AqI)}

In maintaining the mind in this modern world is not only a banning and avoiding liquor and the obligation to seek knowledge as described by classic fiqh scholars, ${ }^{91}$ but one of the most important issues for the modern Muslim intellectuals is more systematic and dynamic rationalization of knowledge of Islam in people empirical life in Indonesia, not rationalism and science as well as its blind taklid. ${ }^{92}$

\footnotetext{
84 Madjid, Islam Kemodernan...., pp. 240-241.

85 Barton, Gagasan Islam Liberal di Indonesia...., pp.128-129.

${ }^{86}$ Madjid, Islam Kemodernan...., p. 178 dan 218-219.

87 M Thahir, "Hubungan Agama dan Negara di Indonesia dalam Pandangan Nurcholish Madjid”, Jurnal Komunikasi dan Sosial Keagamaan, IAIN Samarinda, Vol: XV, No. 1, Juni 2012, p. 44; see journal.iainsamarinda.ac.id/index.php/lentera_journal/article/.../15, retrieved on December 1 ${ }^{\text {st }}$ 2016; Madjid, Islam, Kemodernan dan Keindonesiaan...., pp. 204-206.

88 Madjid, Islam Kemodernan...., p. 241.

${ }^{89}$ Kurniawan, "Pluralisme dan Dialog Agama", Unpublished thesis (Yogyakarta: Fakultas Ushuluddin IAIN Sunan Kalijaga, 2001), pp. 67-68.

${ }^{90}$ Conceptually, Madjid has left a number of thought-inclusive universal faith in the generation of Muslim scientists, among them, Komaruddin Hidayat, Masdar F Mas'udi, Zainun Kamal, zuhairi misrawi, Budhy MunawarRahman, Ahmad Gaus AF and Mu'in Sirry. See Zuhairi Misrawi's work entitled al-Qur'an Kitab Toleransi: Tafsir Tematik Islam Rahmatal Lil Alamin, published by Pustaka Oasis, Jakarta 2010; Nurcholish Madjid dkk, Fiqih Lintas Agama: Membangun Masyarakat Inklusif-Pluralis, Mu'in A Sirry (ed), (Jakarta: Yayasan Wakaf Paramadina dan Asia Foundation, 2004).

${ }^{11}$ Abdul Wahab Khallaf, Ilmu Ushul Fiqh...., p. 201.

92 Madjid, "Pandangan Kontemporer tentang Fiqh: Telaah Problematika hukum Islam di Zaman Modern”, in Budhy Munawar-Rachman (ed.), Kontekstualisasi Doktrin...,p. 378.
} 
Maintaining the minds in the modern world is how to develop the power of the mind or ratio to discover the dynamic scientific truth to reach the absolute truth, the truth of Allah swt. ${ }^{93}$ Therefore, the modern world is identic with the use of ratio in achieving the continuous truth until it reaches the absolute truth (read: rationalization), which is God himself. It is a necessity because it is part of ijtihad which is becoming a necessity in the development of fiqh laws, not rationalism. ${ }^{94}$

As a consequence of the maintaining the mind as explained previously, esoteric define truth can be achieved. Therefore, all religions can meet and go beyond the boundaries of their exoteric element and it make the interfaith fiqh discourse becomes one of the medias to bring the harmony and cooperation among the religions. Therefore, Maria Ulfa's ${ }^{95}$ thinking that considering Madjid's inclusive thought has disrupted the Islamic scholarly discourse, including the fiqh, is not proven. In other hand, M. Amin Abdullah says that Madjid's inclusive Islamic thought has completed the scientific theory of Emile Durkheim. ${ }^{96}$

\section{Maintaining the Soul (Hifdz al-Nafs)}

Internal conflict and interfaith conflict can be avoided and the safety can be made because of the existence of similar vision and cooperation as explained in the previous section. Meanwhile, classic fiqh scholars just discuss about the maintaining the soul related to the prohibition of killing and "qishas" law for those who commit a crime, killing. Besides, they also discuss about the obligation to avoid "madlarat" but classic fiqh does not treat the right and obligation of Muslims and non-Muslims equally. ${ }^{97}$

In this case, Madjid proposes that modern fiqh come to give a right and equality for all mankind without distinguishing the religion aspect, race and other things. The rights and social and politic obligations people should be treated equally, as well as in economics and law. ${ }^{98}$ The values of the public benefit become a fundamental base in protecting the existence of human rights. Therefore, the fiqh prohibits violence, murder and conflict. ${ }^{99}$ Responding the discourse of human right, Madjid stated that human rights are the result of man's work that must be respected and adopted critically. ${ }^{100}$

\footnotetext{
93 Madjid, "Pandangan Kontemporer tentang Fiqh: Telaah Problematika hukum Islam di Zaman Modern”, in Budhy Munawar-Rachman (ed.), Kontekstualisasi Doktrin...,p. 378.

94 The ideology of "rationalism" is rejected by Madjid because it contradicts the principle of hifdz al-din, namely because he denied the truth of revelation as a medium to find and reach the truth, and only recognizes ratio. Likewise "secularism" was rejected by Madjid because it is also contrary to the principle hifdz al-din, which is understood mundane found this worldly life is absolute and final, there is no longer a life after this world. Madjid, Islam Kemodernan...., pp. 218-219.

95 Maria Ulfa, "Mencermati Inklusivisme Agama Nurcholish Madjid", Jurnal KALIMAH, Vol. 11, No. 2, September 2013, p. 249; see also http://ejournal.unida.gontor.ac.id/index.php/kalimah/article/download/94/84, retrieved on September $19^{\text {th }} 2016$

96 M Amin Abdullah, Sumbangan Nurcholish Madjid atas Perkembangan Pemikiran Islam Indonesia, http://nurcholishmadjid.net/?page=news\&action=view\&id=64, retrieved on September 19 th 2016.

${ }^{97}$ Abdul Wahab Khallaf, Ilmu Ushul Fiqh...., p. 201.

98 Madjid, Islam Kemodernan...., p. 158.

${ }^{99}$ Nurcholish Madjid dkk, Fiqih Lintas Agama: Membangun Masyarakat Inklusif-Pluralis, Mu'in A Sirry (ed), (Jakarta: Yayasan Wakaf Paramadina dan Asia Foundation, 2004), pp. 176-180.

100 Muhammad Fuadi, "Konsep Islam Tentang Hak Asasi Manusia Studi Pemikiran Abdurrahman Wahid Dan Nurcholis Madjid" unpublished thesis, (UIN Sunan Kalijaga Yogyakarta), http://digilib.uin-suka.ac.id/6170/, retrieved on December $1^{\text {st }} 2016$.
} 


\section{Maintaining the honor (Hifdz al-'Ird)}

In classic fiqh scholars' point of view, maintaining the honor/descent, generally, only deals with the prohibition of adultery and stoning to death (rajam) and arrange wedding. ${ }^{01}$ Meanwhile, Madjid suggests that the maintaining the honor should not only focus on those aspects but also focus on how to maintain and protect the values of human dignity fairly and egalitarian personally and collectively. Thus, there should not be special treatment for anyone without a legal basis. ${ }^{102}$ Modern figh also teaches the way to think inclusively and universally and it can support confidence, progressiveness and creativity, not apology and inferiority. ${ }^{103}$

Historically, the identity of Islam in Indonesia during the Dutch colonial era became one of the symbols of consciousness and awakening of this nation in maintaining the honor, pride and dignity. Therefore, the identity of Islam at that time became one of the symbols of the national revival Indonesia to fight against the invaders. ${ }^{104}$

\section{Maintaining the property (Hifdz al-Mal)}

Classic figh scholars only discuss about maintaining the property with its obligation to work and seek for the sustenance, performing muamalah and avoid the act of stealing. If people violate them, it will be subjected to the punishment of hand amputation. ${ }^{105}$ Meanwhile, Madjid suggests that the maintaining of the property cannot be achieved simply by handling that partial thing, but it must be done comprehensively and systematically, by realizing the values of social justice in the society to create wealth and prosperity (Surat at-Taubah: 34-35). The modern figh paradigm is going to build a fair economic system with the concept in which everyone should work optimally according to their ability, and there should be a socioeconomic regulation that ensures they meet their basic needs based on minimum standard. ${ }^{106}$

According to Madjid, "in fiqh, these ideals are explained into the provision of halal and haram in economic". In which the there should be no oppression in economic system prevailed (Q.S. 2:27), and there should be no endorsement to all forms of oppression and monopoly (Q.S. 2: 188). Therefore, in its implementation, fiqh teaches the obligation of zakat incorporating with the suggestion to do charity. ${ }^{107}$

\section{CONCLUSION}

Madjid's modern fiqh paradigm was born because of the modernity problem faced by Indonesian society. Therefore, it requires a renewal in the form of paradigm shift. the paradigm shift is started from its ijtihad paradigm, from the classic ijtihad paradigm to the modern fiqh ijtihad paradigm referred to the muhkamat passages which have inclusive and universal values as the testing base in doing ijtihad with the help of science, not mutasyabihat passages that has a technical-practical value.

\footnotetext{
101 Abdul Wahab Khallaf, Ilmu Ushul Fiqh...., p. 201.

102 Madjid, Islam Kemodernan...., p. 159.

103 Thus, "inferiority complex" is inferiority occurs in all fields and aspects of earthly life hereafter for their invasion because of influences the way of thinking to Westernization. Madjid, Islam Kemodernan ...., p. 240 and 254 104 Madjid, Islam Kemodernan...., p. 198.

105 Abdul Wahab Khallaf, Ilmu Ushul Fiqh...., p. 201

106 Madjid, Islam Kemodernan ...., pp. 101-104.

107 Madjid, Islam Kemodernan..., p. 104 and 158; Zirmansyah dkk, Pandangan Masyarakat terhadap Tindak Kekerasan atas Nama Agama: Studi Hubungan Antara Pemahaman Keagamaan Dengan Tindak Kekerasan Atas Nama Agama, (Jakarta: Badan Litbang dan Diklat Kemenag RI, 2010), p. 61.
} 
Meanwhile, the paradigm shift from the classic fiqh paradigm to the modern fiqh paradigm built by Madjid is to ensure the maintenance of the five principles of law construction: (a) maintaining the religion as a mean to realize the depth of faith, unity and internal and interreligion cooperation; (b) maintaining the mind as a mean to realize the dynamics of science as an important element in advancing scientific insights and Islam; (c) maintaining the soul as a mean to respect basic human rights and protect the rights from any violation and oppression; (d) maintaining the honor as a mean to realize the values of personal and collective equality and justice and to avoid the worshiping to other thing except God; and (e) maintaining the property as a mean to maintain economic stability and realize the equalization/equity in the wealth distribution and management.

\section{References}

Abdullah, M Amin, Sumbangan Nurcholish Madjid atas Perkembangan Pemikiran Islam Indonesia, http://nurcholishmadjid.net/?page=news\&action=view\&id=64, retrieved on September $19^{\text {th }} 2016$.

Abdullah, M. Amin. Studi Agama: Normativitas dan Historisitas. Yogyakarta: Pustaka Pelajar,1996.

Abid, Inayatul Ulya dan Nushan, "Pemikiran Thomas Kuhn Dan Relevansinya Terhadap Keilmuan Islam", in FIKRAH: Jurnal Ilmu Aqidah dan Studi Keagamaan STAIN Kudus, Volume 3, No. 2, December 2015.

Abu Zahrah, Muhammad, Ushul Fiqih, trans. Saifullah Ma’sum, Jakarta: Pustaka Firdaus, 1997.

Ali, Achmad, Menguak Teori Hukum dan Teori Peradilan, Jakarta: Kencana, 2009.

Ali, Fachry, Hipotesa tentang Fase Perubahan Pemikiran Nurcholish Madjid, http://nurcholishmadjid.net/index.php?page=news\&action=view\&id=67, retrieved on September $19^{\text {th }} 2016$

Ali, Perveen Shaukat, “Equality As A Basic Human Right in Islam” in Tahir Mahmoud (ed), Human Rights in Islamic Law. New Delhi: Jamia Nagar, 1993.

al-Munawar, Said Agil Husin, Membangun Metodologi Ushul Fiqh: Telaah Konsep al-Nadb \& al-Karahah dalam Istimbath Hukum Islam, Jakarta: Ciputat Press, 2004.

al-Qardlâwî__ûsuf, Madkhal li Dirâsah al-Syarî́ah al-Islâmiyyah, Kairo: Maktabah Wahbah, 2001.

al-Qattan, Manna Khalil, Mabahis fi al-Ulum al-Qur'an, Publisher: Masyurat al-Asr al-Hadits, cet III, 1973.

al-Zukhailî, Wahbah, Ushûl al-Fiqh al-Islâmî Book II. Beirut: Dâr al-Fikr, 1986.

al-Najjar, 'Abd al-Majid, Maqasid al-Syari'ah bi Ab'ad Jadidah, Beirut: Dar al-Gharb al-Islami, 2008.

Anderson, James Norman Dalrymple, Hukum Islam di Dunia Modern, trans. Machnun Husein, Surabaya: CV. Amrpress, 1991.

An-Na'im, Abdullahi Ahmed, "Mahmoud Muhammed Taha and The Crisis In Islamic Law Reform: Implications for Interreligious Relations”, Jurnal of Ecumenical Studies, 25: 1, Winter 1988.

Azizy, A. Qodri A., Eklektisisme Hukum Nasional: Kompetisi Antara Hukum Islam dan Hukum Umum, Yogyakarta: Gama Media, 2002.

Barton, Greg, Gagasan Islam Liberal di Indonesia: Pemikiran Neo-Modernisme Nurcholish Madjid, Djohan Effendi, Ahmad Wahib dan Abdurrahman Wahid, terj. Nanang Tahqiq, Jakarta: Paramadina dan Pustaka Antara, 1999.

Dahlan, Moh, Epistemologi Hukum Islam: Studi Atas Pemikiran Abdullahi Ahmed An-Na'im, Yogyakarta: Doctoral Thesis of UIN Sunan Kalijaga, 2006.

Esposito, John L., and John O. Voll, Demokrasi di Negara-negara Muslim; Problem dan Prospek, trans. Rahmani Astuti, Bandung: Mizan, 1998.

Fuadi, Muhammad, “Konsep Islam Tentang Hak Asasi Manusia Studi Pemikiran Abdurrahman Wahid Dan Nurcholis Madjid" unpublished thesis, UIN Sunan Kalijaga Yogyakarta.

Haryatmoko, “Apa Yang Tersisa dari Agama”, “Majalah Basis”, Nomor 05-06 Mei-Juni, 2002.

Hosen, Ibrahim, “Beberapa Catatan Tentang Reaktualisasi Hukum Islam”, in Muhamad Wahyuni Nafis et al. (eds.), Kontekstualisasi Ajaran Islam 70 Tahun Prof. Dr. H. Munawir Sjadzali, M.A. Jakarta: Paramadina dan IPHI, 1995.

http://digilib.uin-suka.ac.id/6170/, retrieved on December $1^{\text {st }} 2016$. 
http://ejournal.unida.gontor.ac.id/index.php/kalimah/article/download/94/84, retrieved on September 19th $\underline{2016}$

http://ejournal.unida.gontor.ac.id/index.php/kalimah/article/download/94/84, retrieved on September 19th $\underline{2016}$.

http://journal.walisongo.ac.id/index.php/walisongo/article/download/263/244, retrieved on September $19^{\text {th }}$ $\underline{2016}$

http://religio.uinsby.ac.id/index.php/religio/article/download/77/69, retrieved on September 19th 2016.

http://www.kontras.org/uu_ri_ham/UU\%20Nomor\%2039\%20Tahun\%201999\%20tentang\%20Hak\%20Asasi\% 20Manusia.pdf retrieved on February 26 th 2015

Ismatullah, Dedi, Sejarah Sosial Hukum Islam, Bandung: CV Pustaka Setia, 2011.

journal.iain-samarinda.ac.id/index.php/lentera_journal/article/.../15, retrieved on December $1^{\text {st }} 2016$

Khallaf, Abdul Wahab, Ilmu Ushul Fiqh, Tt: Ttp, 1978

Kuhn, Thomas S., The Structure of Scientific Revolution, Chicago: The University of Chicago Press, 1970.

Kurniawan, "Pluralisme dan Dialog Agama", Unpublished thesis, Yogyakarta: Fakultas Ushuluddin IAIN Sunan Kalijaga, 2001.

Madjid, Nurcholish, dkk, Fiqih Lintas Agama: Membangun Masyarakat Inklusif-Pluralis, Mu'in A Sirry (ed), Jakarta: Yayasan Wakaf Paramadina dan Asia Foundation, 2004.

Madjid, Nurcholish, Islam Kemodernan dan Keindonesiaan, Bandung: Mizan, 1998.

Madjid, Nurcholish. "Pergeseran Pengertian "Sunnah ke Hadis": Implikasinya dalam Pengembangan Syariah", "Konsep Asbab al-Nuzul: Relevansinya bagi Pandangan Historis Segi-Segi Tertentu Ajaran Keagamaan",

"Pandangan Kontemporer tentang Fiqh: Telaah Problematika hukum Islam di Zaman Modern", and "Taqlid dan Ijtihad Masalah Kontinuitas dan Kreativitas dalam Memahami Pesan Agama", in Budhy Munawar-Rachman (ed.), Kontekstualisasi Doktrin Islam dalam Sejarah. Jakarta: Paramadina, 1995.

Magnis-Suseno, Franz, Agama, Kebangsaan dan Demokrasi Nurcholish Madjid dan Kemanusiaan, http://nurcholishmadjid.net/index.php?page=news\&action=view\&id=68, retrieved on September $19^{\text {th }} 2016$.

Makmun, Rodli, “Agama di Tengah Jaring-jaring Dunia Modern”, in Religió: Jurnal Studi Agama-agama, Volume 3, No. 2, September 2013.

Maria Ulfa, "Mencermati Inklusivisme Agama Nurcholish Madjid", Jurnal KALIMAH Volume 11, No. 2, September 2013.

Mas'udi, Masdar F., Islam \& Hak-hak Reproduksi Perempuan, Bandung: Mizan, 1997.

Misrawi, Zuhairi, al-Qur'an Kitab Toleransi: Tafsir Tematik Islam Rahmatal Lil Alamin, Jakarta: Pustaka Oasis, 2010.

Nasution, Harun, Pembaruan dalam Islam: Sejarah Pemikiran dan Gagasan, Cet ke-14, Jakarta: Bulan Bintang, 2011.

Rahman, Fazlur, Islam, ter. Ahsin Muhammad, Bandung: Pustaka, 1984.

Rahman, Fazlur, Islam and Modernity: Transformation of an Intellectual Tradition, Chicago: The University of Chicago Press, 1982.

Saifuddin, Lukman Hakim, Pidato Menteri Agama Haul Cak Nur Ke-10,

http://nurcholishmadjid.net/index.php?page=news\&action=view\&id=77, retrieved on September 19th 2016.

Shahct, Joseph, Pengantar Hukum Islam, trans. Joko Supomo, Yogyakarta: Penerbit Islamika, 2003.

Sirry, Mu'in, Polemik Kitab Suci al-Qur'an: Tafsir Reformasi atas Kritik al-Qur'an terhadap Agama Lain, terj. R Cecep Lukman Yasin, Jakarta: Gramedia, 2013.

Sukidi, Teologi Inklusif Cak Nur, Jakarta: Kompas, 2001.

Syamsuri, “Membangun Maqasid Al-Shari'ah Melalui Al-Usuhl Al-Khamsah; Studi Kritis Terhadap Konsep AlGhazali Dan 'Abd Al Majid Al-Najjar”, Kumpulan Makalah Mata Kuliah Reading Arabic Texts Program Doktoral Pascasarjana UIN Sunan Ampel Surabaya 2016.

Taha, Mahmoud Muhammed, The Second Message of Islam, trans. Abdullahi Ahmed An-Na'im, New York: Syracuse University Press, 1987. 
Ulfa, Maria, "Mencermati Inklusivisme Agama Nurcholish Madjid”, Jurnal KALIMAH, Vol. 11, No. 2, September 2013.

Umar, Nasarudin, “Konsep Hukum Modern: Suatu Perspektif Keindonesiaan, Integrasi Sistem Hukum Agama dan Sistem Hukum Nasional”, in Jurnal Walisongo, Volume 22, No. 1, May 2014.

Undang-Undang Republik Indonesia Nomor 38 Tahun 1999 tentang Pengelolaan Zakat. Lembaran Negara Republik Indonesia Tahun 1999 Nomor 164 and Tambahan Lembaran Negara Republik Indonesia Nomor 3885.

Wahid, Abdurrahman, "Islam di Asia Tenggara”, in Abu Zahra ed. Politik Demi Tuhan, Jakarta: Pustaka Hidaya, 1999.

Wahid, Abdurrahman, "Dialog Agama dan Masalah Pendangkalan Agama", in Komaruddin Hidayat and Ahmad Gaus AF, ed, Passing Over: Melintasi Batas Agama, Jakarta : Gramedia, 2001.

Wahid, Abdurrahman, Islamku, Islam Anda, Islam Kita, Jakarta: The Wahid Institute, 2006.

Zirmansyah dkk, Pandangan Masyarakat terhadap Tindak Kekerasan atas Nama Agama: Studi Hubungan Antara Pemahaman Keagamaan Dengan Tindak Kekerasan Atas Nama Agama, Jakarta: Badan Litbang dan Diklat Kemenag RI, 2010. 